Gut, 1982, 23, 276-279

\title{
Progesterone, prolactin, and gynaecomastia in men with liver disease
}

\author{
M J G FARTHING, ${ }^{*}$ J R B GREEN, C R W EDWARDS, AND A M DAWSON \\ From the Departments of Gastroenterology and Endocrinology, St. Bartholomew's Hospital, London
}

SUMMARY Plasma progesterone was raised in 36 of $50(72 \%)$ men with liver disease compared with 20 healthy male control subjects. Plasma progesterone was significantly higher in men with non-alcoholic cirrhosis with gynaecomastia than those without, but no similar relationship was found in men with alcoholic fatty change and alcoholic cirrhosis. Hyperprolactinaemia was found in $14 \%$ of men with liver disease but levels were unrelated to the presence of gynaecomastia. Increased circulating levels of progesterone and prolactin alone do not explain the development of gynaecomastia in patients with liver disease, but progesterone may be an additional factor acting in association with the known disturbances of other sex steroids.

Feminisation commonly occurs in men with liver disease, but the underlying pathophysiological mechanisms are not clearly understood. ${ }^{1}$ Abnormalities of circulating levels of androgens, oestrogens, sex hormone binding globulin, and prolactin occur in liver disease,$^{1-7}$ but these endocrine disturbances relate inconsistently to the clinical findings, particularly to the presence of gynaecomastia.

Although progesterone is required for optimal mammary growth and lactation, ${ }^{8}$ and several reports have implicated progesterone as a factor in the production of gynaecomastia, ${ }^{9-11}$ plasma progesterone concentrations have not been reported in men with liver disease. Hyperprolactinaemia has been associated with drug-induced gynaecomastia ${ }^{12}$ and occurs in some patients with liver disease, ${ }^{72-14}$ although its importance in the production of gynaecomastia in this condition is in doubt.

To clarify these issues we have measured plasma progesterone and serum prolactin in 50 men with liver disease and related the endocrine findings to the aetiology and severity of the liver disease and to the presence of gynaecomastia.

\section{Methods}

SUBJECTS

Fifty men with liver disease (median age 49 years, range 23-63 years) were investigated. According to

\footnotetext{
*Address for correspondence: M J G Farthing, Department of Geographic Medicine, Tufts University School of Medicine, 136 Harrison Avenue, Boston, MA 02111, USA.

Received for publication 28 July 1981
}

the clinical history, physical findings, and liver histology, 16 patients had alcoholic fatty change, 15 alcoholic cirrhosis, and 19 cirrhosis of other aetiologies. Gynaecomastia was defined as the presence of palpable subareolar breast tissue of at least $1 \mathrm{~cm}$ diameter, and an attempt to obtain breast secretion was made by manual compression. A control group of 20 healthy men of a similar age distribution (median age 33 years, range $22-58$ years) was also investigated. Venous blood was withdrawn between 0900 and 1000 hours after subjects had been resting for at least one hour. Plasma and serum were separated rapidly and stored at $-20^{\circ} \mathrm{C}$ until assayed.

\section{ASSAYS}

Plasma progesterone was measured by radioimmunoassay using an antibody raised in a rabbit that had cross-reactivities of under $5 \%$ with all other steriods tested. Plasma samples were extracted with diethyl ether, and separation of bound and free phases was achieved with dextran-coated charcoal. Samples of control and patient plasma were assayed together in a single assay. Serum prolactin was measured by double antibody radioimmunoassay, and results were expressed in $\mathrm{mU} / \mathrm{l}$ against the First International Reference Preparation, MRC 75/504. Inter-assay variation was within $10 \%$. Serum albumin concentration was measured by a Vickers M200 autoanalyser.

\section{STATISTICAL METHODS}

Comparisons between groups of patients and control subjects were examined by the Mann-Whitney $U$ test. 


\section{Results}

Gynaecomastia was present in 17 of the 50 patients with liver disease $(34 \%)$ and in 14 of the 34 cirrhotic patients $(41 \%)$. Manual compression failed to produce breast secretion in any of these patients. Plasma progesterone concentration was significantly higher in patients with liver disease (median $4.0 \mathrm{nmol} / \mathrm{l}$, range $0 \cdot 1-14 \cdot 9$ ) than in control subjects (median $0 \cdot 4$ nmol/l, range $0 \cdot 2-1 \cdot 8 ; \mathrm{P}<0 \cdot 001), 36$ of the 50 patients with liver disease $(72 \%)$ having levels above the normal range. In addition, plasma progesterone was higher in patients with alcoholic fatty change (median $6.8 \mathrm{nmol} / 1$, range $1 \cdot 1-14.9)$ compared with both alcoholic (median $3.0 \mathrm{nmol} / 1$ range $0 \cdot 3-12.7 ; \mathrm{P}<0.01$ ) and non-alcoholic cirrhotic patients (median $2.8 \mathrm{nmol} / \mathrm{l}$, range $0 \cdot 2-7 \cdot 4 ; \mathrm{P}<0 \cdot 01$ ).

Plasma progesterone was significantly higher in non-alcoholic cirrhotic patients with gynaecomastia

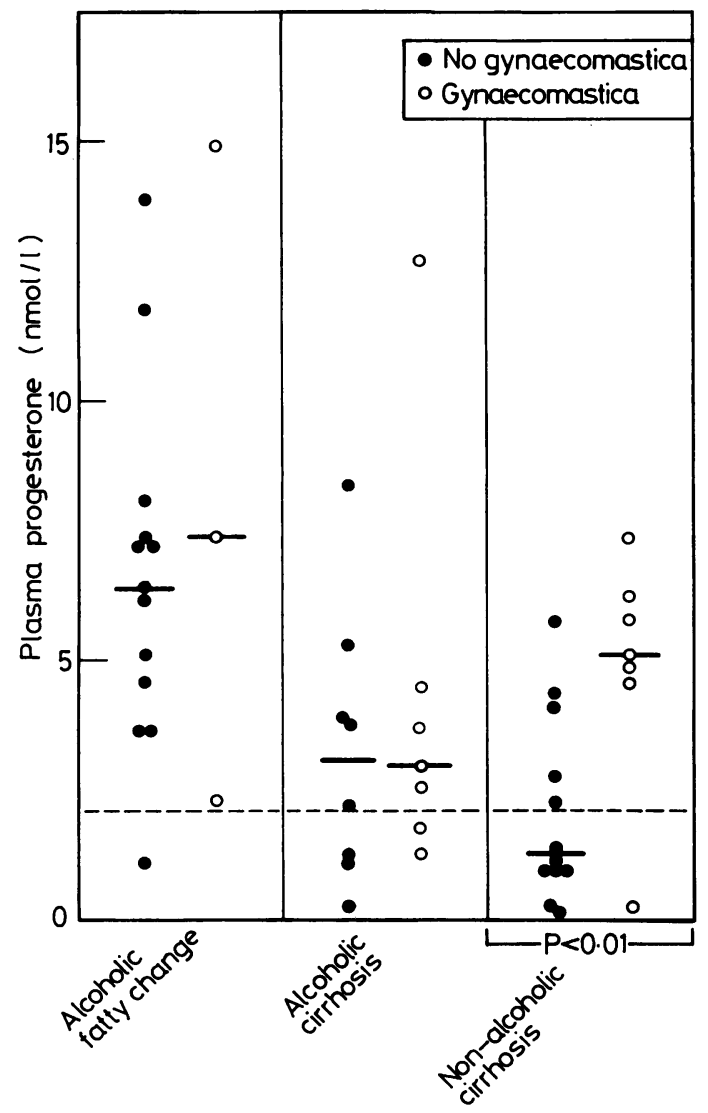

Fig. 1 Plasma progesterone concentration and its relation to hepatic diagnosis and presence of gynaecomastia.

Horizontal broken line represents upper limit of normal for plasma progesterone. than in those without gynaecomastia (Fig. 1), although there was no relation between progesterone concentration and gynaecomastia in the subgroups of patients with alcoholic liver disease. Serum prolactin concentration was raised $(>360 \mathrm{mU} / \mathrm{l})$ in seven of 49 patients (14\%) with liver disease (Fig. 2). None of these patients was receiving drugs known to cause hyperprolactinaemia. ${ }^{15}$ Hyperprolactinaemia occurred equally in all disease subgroups and was not related to the presence of gynaecomastia.

Neither plasma progesterone nor serum prolactin correlated significantly with serum albumin concentration or the patient's age, although serum albumin concentration was significantly higher in patients with alcoholic fatty change (median $39 \mathrm{~g} / \mathrm{l}$, range 30-40) than in those with cirrhosis (median $32 \mathrm{~g} / \mathrm{l}$, range $21-41, \mathrm{P}<0.01$ ). Two of three patients receiving spironolactone had gynaecomastia. Hormone levels in these three patients were not significantly different from levels in patients not receiving spironolactone. Exclusion of the results from these patients from the between-group analyses did not alter the overall findings.

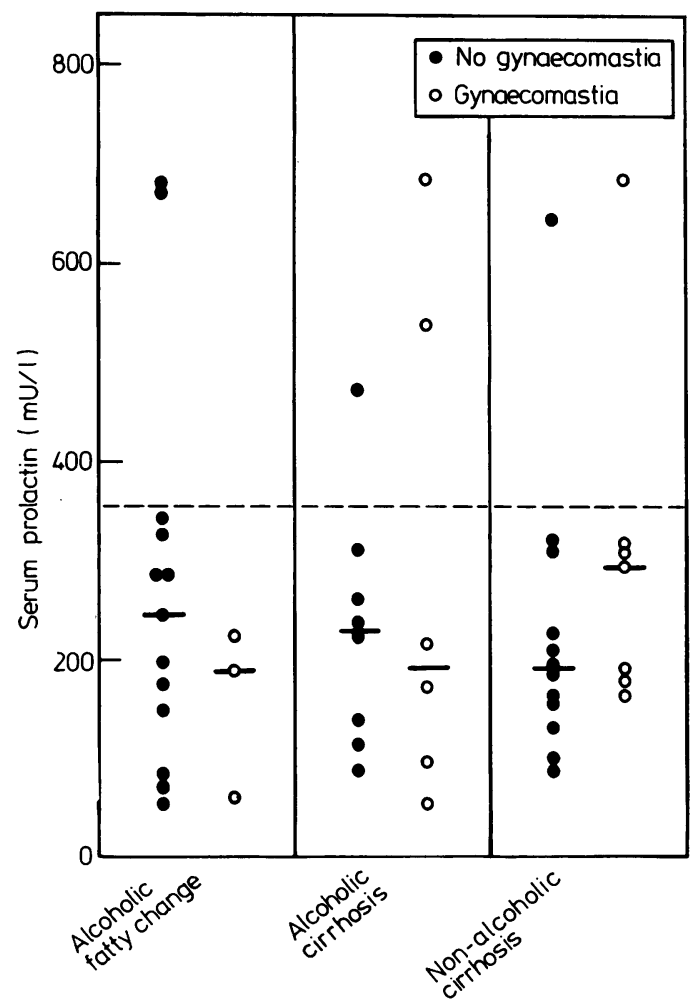

Fig. 2 Serum prolactin concentration in men with liver disease and its relation to hepatic diagnosis and presence of gynaecomastia. Horizontal broken line represents upper limit of normal for serum prolactin. 


\section{Discussion}

Plásma progesterone concentrations above the upper limit of normal for healthy men and within the female range during the follicular phase of the menstrual cycle $^{16}$ were found in $72 \%$ of men with liver disease. This new finding is an abnormality that would appear to be more common than abnormalities in plasma oestrogen concentration.

The significant but unimpressive relation between increased plasma progesterone and the presence of gynaceomastia in men with non-alcoholic cirrhosis fails to provide a universal explanation for the development of gynaecomastia in liver disease. Progesterone may, however, facilitate the action of circulating oestrone, ${ }^{8}$ the weak oestrogen that is raised in men with liver disease and is related to the presence of gynaecomastia. ${ }^{36} \mathrm{An}$ alternative explanation for the failure to find a clear-cut relation between plasma progesterone concentration and the clinical features of feminisation is that the increase in total plasma progesterone may not reflect a parallel change in free hormone concentration. Clearly, direct estimation of free plasma progesterone is needed to determine the contribution, if any, of binding protein abnormalities to the raised total plasma progesterone concentration in men with liver disease.

Our finding of raised progesterone concentration in men with alcoholic fatty change in addition to men with cirrhosis suggests that raised plasma progesterone concentrations are not clearly related to the severity of the liver disease. This is supported by our failure to find a correlation between serum albumin concentration (an indicator of the severity of chronic liver disease) and plasma progesterone concentration.

Spironolactone causes gynaecomastia and produces changes in circulating levels of sex steroids similar to those found in liver disease ${ }^{11} 1718$ - that is, increase in the plasma oestrogen-androgen ratioincluding raised plasma progesterone and its metabolite $17 \alpha$-hydroxyprogesterone. The increase in plasma progesterone in the present study could not, however, be attributed to administration of this drug, although it does suggest that the gynaecomastia of liver disease and that due to spironolactone may have common underlying mechanisms.

Serum prolactin concentration was raised in $14 \%$ of men with liver disease, a value similar to most reported series, ${ }^{3} 7$ although Wernze and Schmitz ${ }^{14}$ found hyperprolactinaemia in $39 \%$ of 75 cirrhotic patients. The failure to find any relation between serum prolactin and the presence of gynaecomastia is in accordance with most earlier studies, ${ }^{7}{ }^{12} 14$ and might be expected, as the gynaecomastia of liver cirrhosis is not associated with galactorrhea.
Although increased plasma progesterone concentration and to a much lesser extent hyperprolactinaemia are found in men with liver disease, neither of these factors can provide a satisfactory explanation for the development of gynaecomastia in this condition. Progesterone may, however, be an additional agent acting with the modest hyperoestrogenaemia and reduced circulating androgen ${ }^{19} 20$ disturbances that at present appear to be the more important abnormalities associated with gynaecomastia.

M J G Farthing gratefully acknowledges the financial support of the Wellcome Trust.

\section{References}

1 Green JRB. Mechanism of hypogonadism in cirrhotic males. Gut 1977; 18:843-53.

2 Van Thiel DH, Lester R, Sherins RJ. Hypogonadism in alcoholic liver disease: evidence for a double effect. Gastroenterology 1974; 67:1188-99.

3 Van Thiel DH, Gavaler JS, Lester R, Loriaux DL, Braunstein GD. Plasma estrone, prolactin, neurophysin and sex steroid-binding globulin in chronic alcoholic men. Metabolism 1975; 24:1015-9.

4 Baker HWG, Burger HG, deKretser DM. Dulmanis A. Hudson B, O'Connor S, Paulsen CA, Durcell N, Rennie GC, Seah CS, Taft HP, Wang C. A study of the endocrine manifestations of hepatic cirrhosis. Q J Med 1976; 45:145-78.

5 Mowat NAG, Edwards CRW, Fisher R, McNeilly AS, Green JRB, Dawson AM. Hypothalamic-pituitarygonadal function in men with cirrhosis of the liver. Gut $1976 ; 17: 345-50$.

6 Green JRB, Mowat NAG, Fisher RA, Anderson DC. Plasma oestrogens in men with chronic liver disease. Gut $1976 ; 17: 426-30$.

7 Morgan MY, Jakobovits AW, Gore MBR, Wills MR, Sherlock S. Serum prolactin in liver disease and its relationship to gynaecomastia. Gut 1978; 19:170-4.

8 Conie AT, Forsyth IA, Hart IC. Growth and development of the mammary gland. In: Hormonal control of lactation. Monographs on Endocrinology. SpringerVerlag, Berlin: 1980.

9 New M. Male pseudohermaphroditism due to $17 \alpha$ hydroxylase deficiency. J Clin Invest 1970); 49:1930-41.

10 Knorr D, Bidlingmaier F. Gynaecomastia in male adolescents. Clin Endocrinol Metab 1975; 4:157-71.

11 Stripp B, Taylor AA, Bartter FC, Gillette JR, Loriaux DL, Easley R, Menard RH. Effect of spironolactone on sex hormones in man. J Clin Endorcrinol Metab 1976; 41:777-81.

12 Turkington RW. Serum prolactin levels in patients with gynaecomastia. J Clin Endocrinol Metab 1972; 34:62-6.

13 Van Thiel DH, Lester R. Alcoholism: its effect on hypothalamic pituitary gonadal function. Gastroenterology 1976; 71:318-27.

14 Wernze H, Schmitz E. Plasma prolactin and prolactin release in liver cirrhosis. Acta Hepatogastroenterol (Stuttg) 1977; 24:97-101. 
15 MacLeod RM. Regulation of prolactin secretion. In: Martini L, Ganong WF, eds Frontiers in neuroendocrinology, vol 4. New York: Raven Press, 1976.

16 Vande Wiele RL, Bogumil J, Dyrenfurth I, Ferin M, Jewelewicz R, Warren M, Rizkallah T, Mikhail G. Mechanisms regulating the menstrual cycle in women. Rec Prog Horm Res 1970; 26:63-103.

17 Loriaux DL, Menard R, Taylor A, Pita JC, Santen R. Spironolactone and endocrine dysfunction. Ann Intern Med 1976; 85:630-6.
18 Rose LI, Underwood RH, Newmark SR, Kisch ES, Willimas GH. Pathophysiology of spironolactoneinduced gynaecomastia. Ann Intern Med 1977; 87: 398-403.

19 Lester R, Eagon PK, Van Thiel DH. Feminisation of the alcoholic: The estrogen/testosterone ratio (E/T). Gastroenterology 1979; 76:415-7.

20 Kley HK. E2/T ratio. Gastroenterology 1979; 76: 1079-80. 